Journal Home Page:

http://perlinguam.journals.ac.za

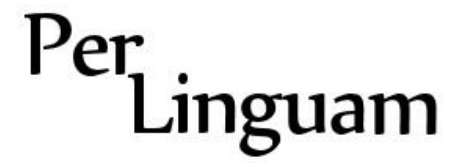

A Journal for Language Learning Tydskrif vir Taalaanleer

\title{
AN OVERVIEW OF GRADE R LITERACY TEACHING AND LEARNING IN INCLUSIVE CLASSROOMS IN SOUTH AFRICA
}

Norma Nel, University of South Africa

Kesh Mohangi, University of South Africa

Soezin Krog, University of South Africa

Oluyemi Stephens, University of South Africa

Pre-school literacy teaching in Early Childhood Education (ECD) inclusive classrooms is crucial in preparing learners for the transition to formal literacy teaching and learning. This article describes a collaborative exploratory research project between a university in South Africa and one in China, in order to gain an overview of early literacy teaching and learning in the two countries. In the case of South Africa, the focus was on Grade R literacy teaching and learning. Teacher participants in three rural schools, three township schools and four inner city schools in Mpumalanga and Gauteng were purposively selected. Data were gathered by means of open-ended questions in a questionnaire, individual interviews with Heads of Departments (HOD) and classroom observations. Coding, categorising and identifying themes were manually conducted. Persistent challenges were identified of which limited resources, low socio-economic conditions, English as the language of learning and teaching (LoLT), inadequate teaching strategies used to implement the Curriculum Assessment Policy Statement (CAPS) and barriers to learning were highlighted. This overview of early literacy teaching and learning in South Africa served as a precursor for the second phase of the project between the two countries.

Keywords: Barriers to learning, Grade R, inclusive education, learning, literacy, reading, teaching

\section{BACKGROUND}

This is a timely article as early childhood development (ECD) and literacy learning and teaching in inclusive classrooms are at the forefront of education systems worldwide. The University of South Africa and the Zhejiang University for International Studies in China embarked on an exploratory, three-phase study beginning in 2013 and comparing South African and Chinese teachers' perceptions of literacy teaching and learning as well as their classroom practices. The aim of Phase One of the project was to determine the position of literacy teaching and learning in the respective countries, with regard to early childhood education, reading development, teacher training, inclusive education and poverty education in rural areas, depicting their teacher and learner conditions and challenges. This article is the first of a series of overviews for Phase One of the project, each written independently from a county's particular perspective. This paper provides an overview of Grade R literacy teaching and learning in selected primary school inclusive classrooms in two provinces in South Africa. 


\section{EARLY LITERACY DEVELOPMENT IN SOUTH AFRICA}

The use of the language of learning and teaching (LoLT) in multilingual societies such as South Africa is a very important issue to consider. The use of the home language as LoLT, whilst also providing an additional language in the early years, is pivotal as it is in line with the Education for All goals (EFA) (Department of Education, 2008). The South African Education system employs eleven home languages for education in the first three grades (including Grade R) in primary schools which is then followed by English medium for approximately 80\% of speakers of African languages (Heugh, 2013: 215). The Language in Education Policy (LiEP) stipulates that "all learners shall be offered their LoLT and at least one additional approved language as a subject". The selection of LoLT at a school depends on the learners' and their parents' choice mainly (Department of Basic Education, 2010:5-6)

The White Paper 6: Special Needs Education, Building an Inclusive Education and Training System (Department of Education, 2001:7) refers to 'inappropriate languages or language of learning and teaching' which create barriers to learning. ${ }^{\text {. }}$. The implication is that there is a need for schools to serve a 'wider school population' and subsequently to provide support for English Second Language (ESL) learners (Nel, 2011: 168) Teachers in general are thus compelled to teach basic levels of English in order for learners to survive in their schools and society, but often they are not equipped with the skills to meet the diverse needs of these learners, and they themselves may be teaching in English which is their second or third language (Nel 2011: 169).

Nel (2011:167-169) expressed concern regarding learners' early learning and literacy in South Africa as many African language-speaking parents are inclined to enrol their children in schools where the LoLT is English rather than an African language. However the reality is that in the majority of rural and township schools approximately $65 \%$ schools use an African language as the LoLT and town schools which have English as their LoLT constitute less than $20 \%$ of schools in South Africa. This means that learners in these schools need to learn English and at the same time learn the curriculum content in English, which is their second or third language (DoBE 2010).

It is distressing to note the Report on the Annual National Assessments (ANA) 2014 (Grades 1-6 and 9) which reflects the national average percentage marks for language as follows: Grade $1(60 \%)$ and Grade $3(60 \%)$. The mean scores for the Intermediate Phase (Grades 4-6) and Grade 9 in comparison are much lower, that is a maximum average mark of 57\% (Home Language) and a 47\% minimum in Grade 5 (First Additional Language) (Department of Education, 2014). These scores have serious implications for reading literacy, which is the foundation for academic success (Zuze \& Reddy 2013: 100).

It is encouraging to note that the Department of Education (DoE) has made an effort to put the National Strategy for Reading in place. As part of the development of this strategy, South Africa joined UNESCO Literacy Decade 2003-2013 and the Education for All (EFA) campaign which aimed at increasing the literacy rates by 50\% by 2015 (DoE 2008:4). This is a commendable campaign, however, it is questionable, as Atmore (2013:159-160) claims that the development of basic reading skills, writing, numeracy and life skills is essential in the first six years of a child's life for optimal social and educational development (i.e. before entering Grade 1).

\footnotetext{
1 "Inappropriate languages" in this context refer to those languages which are other than the learners' mother tongue.

Per Linguam 2016 32(2):47-65
}

http://dx.doi.org/10.5785/32-2-651 
To be a successful reader requires one to be able to link meaning to specific words which is necessary to develop analytical skills. Environmental, school and biological factors all influence reading literacy development (Zuze \& Reddy, 2014:105). Literacy knowledge and skills lay the foundation for reading and writing (early literacy) in all academic tasks. During early literacy acquisition, the child is able to explore the world through books, story-telling and other reading and writing activities. The learner is able to learn about enjoyable topics and acquire knowledge and concepts and to experience success in school and elsewhere. Through literacy knowledge and skills, bilingual learners are able to demonstrate their abilities, skills and languages in a second language as well as their home language (US Department of Education, 2010:1)

Despite an effort to promote literacy, South Africa is contending with numerous challenges relating to infrastructure (no running water, electricity and sanitation, dilapidated buildings, huge teacher/learner ratios, lack of nutrition, under qualified teachers, as well as a lack of institutional capacity and funding (Atmore, 2013:155/6). Low levels of literacy are further exacerbated by a lack of libraries (as only about $7 \%$ of schools in South Africa have functional school libraries), no books at learners' homes, scarcity of books in African languages, wrong levels of books available, as well as no books in classrooms (Department of Education, 2008:4).

In a study by O'Carroll (2011:7) early literacy development in two disadvantaged communities in Cape Town, South Africa revealed that almost half of learners who enter Grade 1 are not able to recognise any letters. However, by means of an intervention programme in Grade $\mathrm{R}$ (reception year) the learners were able to learn letter-sounds whilst learning language skills, emergent writing and print concepts. This points to the lack of an emphasis in the Grade $\mathrm{R}$ curriculum regarding early literacy development and calls for quality Grade $\mathrm{R}$ teacher training programmes with an emphasis on emergent literacy. In the Social Franchising for ECD Literature Review of 2014, Murris (2014) expresses concern about the small emphasis that is put on reading for meaning, thinking skills needed to make sense of complex texts and how to teach it in the Foundation Phase (Grades R - 1) in South Africa.

To be a successful reader requires one to be able to link meaning to specific words which is necessary to develop analytical skills. Environmental, school and biological factors all influence reading literacy development (Zuze \& Reddy, 2014:105). Literacy knowledge and skills lay the foundation for reading and writing (early literacy) in all academic tasks. During early literacy acquisition, the child is able to explore the world through books, story-telling and other reading and writing activities. The learner is able to learn about enjoyable topics and acquire knowledge and concepts and to experience success in school and elsewhere. Through literacy knowledge and skills, bilingual learners are able to demonstrate their abilities, skills and languages in a second language as well as their home language (US Department of Education, 2010:1)

In the following section the Curriculum Policy Statement (CAPS): Foundation Phase (Home language Grades R-3) is discussed as it informs the study.

\section{CURRICULUM AND ASSESSMENT POLICY STATEMENT: FOUNDATION PHASE (Home language Grades R-3)}

The CAPS for Grade R language learning promotes integration and play-based learning, the latter being mediated by the teacher through incidental learning opportunities during free play. Activities include, fine and gross motor development, art activities, story rings, the 
fantasy corner, drama and role play. The daily programme is geared towards teachable moments. Enhanced literacy learning occurs through direct intervention, planned mediated activities, incidental learning opportunities and child-initiated activities either during routine period or free play (Department of Education 2011a).

Key areas which need development are visual perception, visual motor integration and motor skills (Pienaar, Barhorst \& Twisk, 2013:277). These authors found that the relationship between academic performance, socio-economic status and perceptual motor skills in Grade 1 played an important role in their educational progress in formal schooling. Basic skills in maths, reading and writing are the most affected areas found in learners who live in high risk environments. When they enter Grade R, these children are expected, amongst other things, to already be able to identify words, recognise words made up of sounds, segment oral sentences into individual words, recognise initial sounds, read high frequency word, answer question based on a story read, form letters using finger painting and copy words and letters (Department Basic Education 2011b:16)

Phonemic awareness can be promoted during daily routines, snack time and tidy up times, such as those whose names begin with $\mathrm{R}$ can go to the bathroom. Playing fun sound and word games such as 'I spy...', and 'what rhymes with .... (dog)' can also be used. Visual memory games such as Bingo and other computer software programme scan encourage visual memory. Outdoor play, either free or structured (climbing, riding on a cycle track, crawling through a tunnel, following signs), helps develop spatial awareness, reading and writing. The fantasy corner promotes listening and speaking (Department of Education, 2011a:24-25).

During free play teachers are encouraged to ask questions to extend and enlarge vocabulary by encouraging the child to give alternate answers and solve problems. Children learn best through movement and interacting with concrete objects. Observation is considered the best from of assessment in order to obtain a holistic picture of growth points and strengths of the learner (Department of Education, 2011a:24-25).

With this background in mind, and as a forerunner for the empirical research phase, we needed a recent and reliable reflection of what is currently happening on the ground in terms of preparing learners in Grade $\mathrm{R}$ for formal reading in Grade 1 and what is being implemented to address the barriers that learners are experiencing in gaining emergent literacy skills. The following research question guided the pilot study:

- What are Grade R teachers' practices in teaching literacy skills in Grade R classrooms and how do they address barriers to literacy learning?

\section{METHODOLOGY}

One of the aims of this project was to conduct empirical research into teachers' literacy perceptions and classroom practices in early literacy teaching and development. In this paper, we report on the findings of the first phase of the project and provide an overview of Grade $\mathrm{R}$ teachers' attitude towards teaching reading literacy in Grade R. We also establish the status of current literacy teaching practices for learners, including those with barriers to learning. A qualitative approach was employed in this phase. Ethical clearance was obtained from the Unisa Ethics Committee and a Memorandum of Understanding was signed by the authorities of the two participating institutions (20 April/1127381/MC). 


\section{Site selection}

The study was conducted in 10 schools in two cities in the Gauteng Province and one city in the Mpumalanga Province (cf table 1). The selected primary schools (with attached ECD sites) in Gauteng Province are situated in townships (3) and a rural area (3), while in Mpumalanga Province they are situated in a metropolitan area (city) (4). The LoLT in the township schools is officially English yet African languages (depending on the choice of the school) are spoken in class. The LoLT in inner-city schools is English and Afrikaans (dual medium) and English is used in the rural schools despite the fact that the majority of the learners' mother tongue is not English. In the three township schools, the LoLT is a combination of Tswana, Sepedi and isiZulu. It needs to be noted that the Grade R classes in this study are ECD facilities that are attached to public schools (except for one private school). They therefore have a more structured governance and financial reporting system than schools which do not fall under the Department of Education.

The schools have well-established school governing bodies as well as effective ways of being accountable to parents (Atmore, 2013:157-8). In the township schools and the rural schools all the learners are black, while in the inner-city schools the classes are a mixture of white, black, Indian and coloured learners.

\section{Teacher participant selection}

Convenient sampling was used to select schools which had up to six but not less than three Grade R classes (cf table 1). The researchers approached the school principals to request willing teachers to participate in the study. A total of 31 Grade $\mathrm{R}$ teachers participated in the study with an average teacher-learner ratio of 30 learners per class. The teachers had different levels and years of teaching experience and were teaching either younger, older or mixed-age Grade R learners. Eight teachers from the rural schools participated, six from the township schools and 17 from the inner-city schools. In addition, ten heads of department, one from each school, were interviewed.

The qualifications of the teachers from all schools ranged from a teacher certificate, to a level five certificate (Grade 12 plus 1 year training) to an Early Childhood Development diploma. Some teachers had no formal qualifications. Such limited levels of formal qualifications for teaching purposes are a reason for great concern; Atmore (2013:157) refers to a study in the Western Cape on ECD services where it was found that only 35\% of ECD practitioners who are responsible for infants and toddlers had some form of an ECD qualification. In this study, only $4 \%$ of practitioners who were responsible for the older children had some form of an ECD qualification. 
Table 1: Grade R: school location, class sizes, race and LoLT

\begin{tabular}{|c|c|c|c|c|c|c|c|c|c|c|c|}
\hline $\begin{array}{l}\overline{8} \\
0 \\
\overline{0} \\
n\end{array}$ & $\begin{array}{l}0 \\
. \Xi \\
0 \\
0 \\
0\end{array}$ & 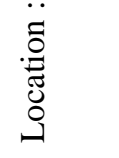 & 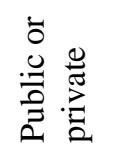 & 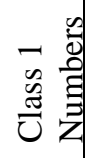 & 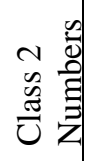 & 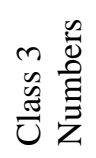 & 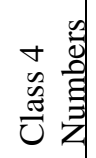 & 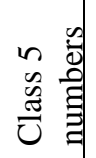 & 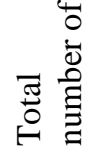 & 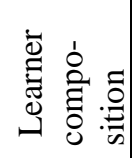 & 車 \\
\hline $\begin{array}{l}\text { School } \\
\text { A }\end{array}$ & $\begin{array}{l}\text { Mpuma- } \\
\text { langa }\end{array}$ & $\begin{array}{l}\text { Inner } \\
\text { city }\end{array}$ & Private & 19 & 19 & 18 & 17 & & 73 & $\begin{array}{l}\text { Mixed } \\
*\end{array}$ & $\begin{array}{l}\text { English } \\
\& \text { Afri- } \\
\text { kaans }\end{array}$ \\
\hline $\begin{array}{l}\text { School } \\
\text { B }\end{array}$ & $\begin{array}{l}\text { Mpuma- } \\
\text { langa }\end{array}$ & $\begin{array}{l}\text { Inner } \\
\text { city }\end{array}$ & Public & 31 & 30 & 31 & - & - & 92 & $\begin{array}{l}\text { Mixed } \\
*\end{array}$ & $\begin{array}{l}\text { English } \\
\& \text { Afri- } \\
\text { kaans }\end{array}$ \\
\hline $\begin{array}{l}\text { School } \\
\text { C }\end{array}$ & $\begin{array}{l}\text { Mpuma- } \\
\text { langa }\end{array}$ & $\begin{array}{l}\text { Inner } \\
\text { city }\end{array}$ & Public & 24 & 26 & 24 & 25 & 26 & 125 & $\begin{array}{l}\text { Mixed } \\
*\end{array}$ & $\begin{array}{l}\text { English } \\
\& \text { Afri- } \\
\text { kaans }\end{array}$ \\
\hline $\begin{array}{l}\text { School } \\
\text { D }\end{array}$ & $\begin{array}{l}\text { Mpuma- } \\
\text { langa }\end{array}$ & $\begin{array}{l}\text { Inner } \\
\text { city }\end{array}$ & public & 24 & 23 & 23 & 24 & 25 & 119 & $\begin{array}{l}\text { Mixed } \\
*\end{array}$ & $\begin{array}{l}\text { English } \\
\text { \& Afri- } \\
\text { kaans }\end{array}$ \\
\hline $\begin{array}{l}\text { School } \\
\text { E }\end{array}$ & Gauteng & Rural & Public & 34 & 35 & 36 & - & - & 105 & $\begin{array}{l}\text { Black } \\
\text { White }\end{array}$ & English \\
\hline $\begin{array}{l}\text { School } \\
\text { F }\end{array}$ & Gauteng & Rural & Public & 33 & 35 & 32 & - & - & 73 & $\begin{array}{l}\text { Black } \\
\text { White }\end{array}$ & English \\
\hline $\begin{array}{l}\text { School } \\
\text { G } \\
\end{array}$ & Gauteng & Rural & Public & 35 & 38 & - & - & - & 100 & Black & English \\
\hline $\begin{array}{l}\text { School } \\
\mathrm{H}\end{array}$ & Gauteng & $\begin{array}{l}\text { Town- } \\
\text { ship }\end{array}$ & Public & 37 & 38 & - & - & - & 75 & Black & $\begin{array}{l}\text { African } \\
\text { lang- } \\
\text { uage }\end{array}$ \\
\hline $\begin{array}{l}\text { School } \\
\text { I }\end{array}$ & Gauteng & $\begin{array}{l}\text { Town- } \\
\text { ship }\end{array}$ & Public & 32 & 42 & - & - & - & 74 & Black & $\begin{array}{l}\text { African } \\
\text { languag } \\
\mathrm{e}\end{array}$ \\
\hline $\begin{array}{l}\text { School } \\
\text { J }\end{array}$ & Gauteng & $\begin{array}{l}\text { Town- } \\
\text { ship }\end{array}$ & Public & 43 & 36 & - & - & - & 79 & Black & $\begin{array}{l}\text { African } \\
\text { languag } \\
\mathrm{e}\end{array}$ \\
\hline
\end{tabular}

*Mixed schools consisted of black, white, coloured and Indian learners

\section{DATA COLLECTION}

According to Matthews and Ross (2010:181) data collection is a practical activity which has to be carried out within certain time, spatial and resources constraints. In the case of this particular study data was collected using questionnaires, observations and interviews.

A questionnaire consisting of both closed and open-ended questions was completed by all 31 teachers prior to the observations. For the purpose of this article responses to the open-ended questions were examined. Responses to open-ended questions as opposed to prior selected questionnaire categories enable one to see the world as the respondents see it by way of revealing their depth of emotions, the way they organise their world and what their thoughts, experiences and basic perceptions are (Patton, 2002:21). In this study, the open-ended questions served to supplement and provide detail to pertinent issues relating to reading instruction gained through the closed questions in the questionnaire.

Following the collection of the completed questionnaires, observations of literacy lessons were conducted in all the Grade $\mathrm{R}$ classes of the participating schools. The researchers sat discreetly at the back of the classrooms during the lessons which were conducted while the learners were seated on the carpets facing their teachers. An observation schedule was used 
and additional notes were made by the researchers during the observed lesson. Thereafter, researchers conducted individual interviews with Heads of Department of the Foundation Phase. Although interviews are a major source of information, this method does have its limitations and therefore participant/non-participant observations of the complexities of the phenomenon can be considered as the best research method (McMillian \& Schumacker, 2010; Creswell, 2007). Hence we chose three data collection methods to cross-check the data and limit any inconsistencies or biases in the three sources of data. The discussion now turns to the data analysis.

\section{DATA ANALYSIS}

For this paper, we examined the teachers' responses to the open-ended questions of the questionnaire that pertained to literacy teaching and barriers to learning. Secondly, we analysed our responses on the Grade R classes' observation schedules and reflected on them in order to gain insight into how different aspects of literacy were being taught. The remaining part of the questionnaire provided quantitative data for a follow-up article. By ascertaining these two dimensions and by integrating the HODs' interview responses, we collated all the data and recorded it in tabular form containing three columns with separate headings, namely open-ended questions, observations and HOD interview responses.

By preparing, organising and displaying the data in this manner as an analytic strategy, we were able to peruse each of the columns and indicate contrasts and comparisons. This enabled us to reduce the data into themes through a process of coding and condensing the codes. From the transcribed tapes, a part of the text was identified by the researchers who then assigned a code label and went through the data in search of all text parts that had the same code label. Ultimately the data were represented in a discussion/narrative (Creswell, 2007:148 \& 164) and in so doing, answered our research question.

\section{FINDINGS AND DISCUSSION}

The teachers' responses to the open-ended questions from the questionnaire formed the central focus of analysis while the data from the observations and interviews with the Heads of Departments (HOD) were complementary. The open-ended questions appeared in two sections of the questionnaire, namely Reading Instruction and Barriers to Learning. The classroom activities that were observed included: story ring, teaching a letter of the alphabet and teaching rhymes.

For the purpose of this article, we discuss the themes pertaining to our research question, namely Literacy Teaching and Addressing Barriers to Learning. These themes were generated from and aligned with the patterns that emerged from the analysis of the questionnaires, interviews and observations.

Table 2: Emergent themes vs data collection method

\begin{tabular}{|l|l|l|}
\hline Open-ended questions & Observations & HOD interviews \\
\hline 1. Literacy teaching & $\begin{array}{l}\text { - Literacy lesson/activities } \\
\text { - Teacher /learner characteristics } \\
\text { - School and classroom } \\
\text { environment }\end{array}$ & $\begin{array}{l}\text { • Literacy teaching } \\
\text { - Teachers } \\
\bullet \text { Management }\end{array}$ \\
\hline $\begin{array}{l}\text { 2. Addressing barriers to } \\
\text { learning }\end{array}$ & $\bullet$ Barriers & $\bullet$ Barriers \\
\hline
\end{tabular}




\section{THEME 1: Literacy teaching (data obtained from open-ended questions, observations and HOD interviews)}

The general findings of literacy teaching and learning, pertaining to the different school contexts, are discussed here. Thereafter the researchers relate their findings on literacy teaching and addressing barriers to learning within the specific school contexts as their challenges differed to a large extent.

All lessons were guided by CAPS: for example a phonics lesson, a listening and speaking lesson and in some cases it was supplemented by approaches to teaching phonics such as either the Teaching Handwriting, Reading, and Spelling Skills programme (THRASS) (Condy, Chigona, Chettyr \& Thornhill, 2010:261), Jolly phonic (or both) and Letterland (McCardle \& Chhabra 2004:180). However, CAPS recommends a balanced approach which includes explicit phonics instruction. From the observations and also responses to the questions in the questionnaire, it could be concluded that although the teachers' knowledge of CAPS was reasonable, many teachers experienced difficulty integrating all areas of CAPS into their literacy teaching. Teachers also appeared to have little knowledge of literacy teaching.

In most cases the language of learning and teaching was English or Afrikaans, depending on whether it was an English or Afrikaans school, and in some cases home languages such as Tswana, Sepedi and Zulu, were spoken as a means of code-switching. In all the schools, learners were on different levels of the LoLT. Janks and Makalela (2013:224) assert that in Gauteng, all official South African languages are spoken and mixed daily, resulting in school children speaking multiple languages. In townships, a large number of children are multilingual and have difficulty in identifying their mother tongue, thus they resort to 'kasitaal' (a hybrid township language) or so-called Sowetan. Three lessons in the township schools were conducted in Sepedi. Learners answered questions mainly in a chorus and seemed reluctant to respond individually.

During the lessons, it was observed that English second language teachers had difficulty pronouncing words appropriately in English and learners imitated their inaccurate pronunciation. It was clear that some teachers' knowledge of English and English usage was limited. In some cases the teachers would tell a story without any visuals and learners appeared to be bored. Story sharing was not evident in all classes. Observations revealed that teachers asked questions which were literal with very few higher-order thinking questions and very little time was allowed for answering. Most lessons were teacher directed with no variation and consisted mostly of instructions. A great deal of rote learning took place in the majority of the classes and learners answered in unison.

Teachers were requested to highlight how they encouraged listening and speaking among their learners. Some teachers adopted a formal teaching approach to teaching listening skills (such as reading stories and asking questions, reciting short nursery rhymes and learning songs and structured writing), while others have an informal approach (such as listening to instructions during the daily routines). The majority of the literacy activities took place on the carpet where learners participated in a group which seemed to enhance teacher-learner interaction. 


\section{Activities for teaching literacy}

Listed below are the most common activities that teachers used to teach literacy:

Table 3: Activities used to teach literacy

\section{Observations \\ 1. Learners practice reading one another's names. \\ 2. A THRASS chart is shown and learners read the words.}

3. Teacher tells the story and shows accompanying pictures asking questions about the pictures e.g. 'What other birds can you remember that we learnt about?'; 'Can you remember the girl's name?'; and 'Who wants to be the witch?'. Learners are told to draw part of the story they liked best and then they tell the rest of the class about their picture.

4. Learners draw what they did over the weekend/holiday on their whiteboards and then tell the rest of the class.

5. Teacher pages through a Big Book and asks individual learners: 'Which word starts with "a"?; What sound does it make?; Say a word that makes the "a" sound.' A song is played about the ' $a$ ' sound and the learners sing and do the actions together. The teacher writes the sound on the board and learners sound it. The word CAP is written on the board and the learners say the word.

6. Other questions are asked e.g. "What is the sound we are learning about?'; 'What is the first sound and what is the name of the sound?'; 'What is the last sound you hear?'; 'What animals did you hear?'; 'What sound does hammer begin with everybody make the sound, what did we hear?'; and 'If I say Jake, snake does it sound the same?'

7. Teacher first teaches the sound, then learners say words that start with the sound, learners write the sound in the sandpit and on whiteboards, trace the sound and draw pictures starting with the sound and cut out the sound and draw pictures.

8. Teacher asks: 'What sound did we learn yesterday?' and shows sound chart.
Open-ended questions (questionnaires)

1. The teachers read a story; teacher sounds, flashes sight word pictures, and discusses words which are shown visually.

2. Learners:

- listen to audio stories

- make their own books

- read calendar, weather words, high frequency words

- draw and make up own stories

- do word building exercises

- act out stories

- bring objects for show-and-tell activity

- explain what is happening in a picture

- do sentence completion

- cut out pictures from magazines to an instruction e.g. cars, fruits

- choose the story they like

- engage in poster discussion

- do relaxation activities

- write names in the air

- build letters with blocks

- read labels

- listen to a song played on an iPad.

3. Letterland CD and books, Jolly phonics and THRASS are used.

4. Teacher reads a story and leaves out the ending and learners are asked to tell how they think the story ends.

5. Learners identify sounds that do not belong in a sequence of sounds.

6. Teacher reads stories and asks learners to identify the beginning and end of the story.

7. Teacher shows learners the story on video. 
Teacher reads lesson on the back of the sound chart and asks which words they heard beginning with the sound. Teacher does incidental talk, e.g. M for milk - and what does one use to measure the milk? (M........ jug). Teacher continues with rhyme words - 'Which words rhyme with "mug?"; and "Which words rhyme in: "The cat sits on the mat?",

9. Teacher says: 'We say D-U-CK - now clap and sound'; 'How many sounds do you see but you only say e as in FISH?'

The teachers in the study explained that many learners experience difficulty remembering sight words and have difficulty with word recognition which has a huge impact on their ability to read fluently. Teachers explained that this is a common problem which they were not able to give reasons for. Such on-going challenges could imply that teachers may not have adequate knowledge on how to improve the listening and reading skills of learners. Furthermore, the researchers observed that most of the learners were not able to read or identify letters of the alphabet, for example to recognise initial consonants and vowels visually and aurally in Grade R. This finding confirms what O'Carroll (2011:7) found that almost half of Grade 1 learners in a low socio-economic area in Cape Town were not able to recognise letters. This finding also lends credence to Fleisch's (2008:12-22) warning that poor literacy constitutes a 'crisis' in South African education.

The discussion now turns to literacy teaching and the socio-economic factors, as barriers to learning in the specific school contexts. The barriers that teachers mentioned included many learners who come to school hungry, have language delays and are not stimulated by their parents. Furthermore, as many parents appear to have low levels of literacy, they prefer to avoid getting involved in the school environment.

\section{Rural, township and low socio-economic areas}

All the classes observed were attached to the local school in the community. The majority of learners attending these schools are from townships, informal settlements and low socioeconomic backgrounds. In these schools (listed $\mathrm{E}$ to $\mathrm{J}$ in Table 1) the teacher/learner ratios were large, and in some cases age groups were combined.

Schools $E$ to $G$ (rural schools) have to cope with little or no resources, for example, no dusters to clean blackboards, no visual aids, using blankets for learners to sit on instead of a carpet as they are not able to generate funds to purchase these items. Two out of the three rural schools are non-paying fee schools. Zuze and Reddy (2014:105-106) consider improved school resources as a way to make an impact on literacy scores, for example, expanding school libraries and being sensitive to the diverse learner population.

Very few free drawings were exhibited on classroom walls as most of the learners' work was completed on worksheets. Walls were somewhat bare. Teacher and learning aids were visible such as reading corners, however these contained only a few old tattered story books and magazines. Where there were Letterland pictures available, they were often set too high for learners to see. Even though number cards, picture stories, weather boards, weekday charts, 
months of the year charts, health charts, healthy living charts, road safety charts, animal charts, and colour charts were displayed on the walls, the classes were generally lacking as a print-rich environment. Incidental reading opportunities were minimal, for example, there were no children's names on pigeon holes or on tables and theme tables were empty. Stories read by one teacher were from a very small book and learners could hardly see the small pictures; black board writing was too small and faded for learners to read.

One school has a feeding scheme in place; however the donor's funds are limited. Most nutrition interventions at ECD centres are provided by non-profit organisations and/or faithbased organisations (Atmore, 2013:156). The rest of the $\mathrm{E}$ to $\mathrm{J}$ schools qualify for feeding schemes provided by the DBE. In another, which is a fairly well-resourced school, German volunteers assisted teachers in literacy teaching and an IT reading programme was being run by a volunteer teacher. University of South Africa students were also doing their teaching practice in some of the schools. The DBE provides all classes with the CAPS learning books, yet an insufficient number of books were provided and in most cases the books had not been used which may suggest that teachers do not deem books in Grade R important and that other activities such as outside play take prevalence.

Classes appeared dusty and untidy and in are some cases there was no water supply and no heating. Sections of ceilings were missing, making unsafe for the children. In some areas, containers served as classrooms where space was limited for free activities, there was no space for teachers to store teaching and learning aids, and chairs had to be stacked up and only stacked down for writing activities. These classes were disorganised and confusion existed when children were told to draw pictures related to the story but were not given an idea of which object words represented.

\section{Public inner-city schools}

Although these schools (Schools A to D on Table 1) are situated in the city, many of the learners come from townships, informal settlements, and low socio-economic families within the city. All races are represented in these schools. In one Afrikaans school (school C) the majority of the learners were white, in school B's English class all learners were black, and in the Afrikaans class the learners were all white. All the teachers were white in school A. The qualifications of teachers in these schools ranged from an ECD certificate to B.Ed degrees.

The public inner-city schools in this study have their own budgets and are able to generate funds. These classes were better equipped with resources and teaching aids. One school had new buildings, built on a soccer field adjacent to the primary school and is well-resourced. In the English classes, THRASS reading cards and Jolly phonics cards were displayed for learners to see. Public township or city schools are provided with CAPS learner books by the Education Department, but not in sufficient number so learners need to share books. Children's art work is displayed on the walls as well as inter alia, birthday charts, pictures of body parts, weather board, months of the year, alphabet and others. Reading corners (with adequate books) and fantasy corners were seen in all classes, and tape recorders, bingo, puzzles, big readers and whiteboards were also displayed. In one school there was a media centre with computers but it was rarely used and learners were not allowed to borrow books even though the library was well-equipped with books, pictures and CDs.

\section{Private school}

One of the research sites for this study was a private school which is situated in what appears to be a higher socio-economic status area in Mpumalanga. In the English classes the children 
are mostly black with a few white children and in the Afrikaans class the children were all white. There were between 15 and 19 learners in each class. All the teachers were white with either a B.Ed degree, a B.Ed Hons, or were busy with further qualifications. The Grade R classes are attached to the school which is newly built. The Grade R classes are in their own section of the school and are well-resourced. Over and above the resources in the other schools, they had extra teaching and learning aids such as puppets, whiteboards for each learner, felt-boards, as well as a wide variety of books and magazines, toys, paintbrushes and the like.

It seems clear that adequate funding leads to better resources with the likelihood of improved learning and teaching opportunities. Since 2001 the government has funded Grade R in two ways. Firstly, provincial governments funded grants to community-based ECD centres on a per-learner basis. Secondly, a direct grant in aid from provincial education departments (PEDs) to school governing bodies which employ the teachers, finance Grade $\mathrm{R}$ in public primary schools. Subsidisation of Grade $\mathrm{R}$ is poverty targeted but 'lags substantially behind funding for other grades in the same school. In 2005, it was approximately seven times less than for a Grade 1 learner (Biersteker \& Dawes, 2008:200).

We will now turn to a discussion of theme 2, namely Addressing Barriers to Learning.

\section{THEME 2: Addressing barriers to learning with reference to literacy teaching and learning}

From the observations of the literacy lessons, in most of the township and rural schools barriers such as limited building resources and print-based resources exist. Other barriers included management-based issues, home-based issues and teaching issues. The LoLT was the learners' second or third language which is one of the biggest barriers the learners are facing as well as poor quality teaching which is typified by much repetition, rote learning and teacher talk. From the interviews with the Heads of Department, other barriers to learning identified include inability of the learners to remember sight words (short and long-term memory), word recognition, language delays, parents in need of stimulation training, young parents and absenteeism, financial constraints, teacher overload, and poor teacher attitudes. In some of the public town schools these barriers were also present, especially in the low socioeconomic areas.

From the open-ended questions in the questionnaire educators were asked how they address various barriers to learning. These barriers are related to areas of literacy (which feature in the CAPS - Grades R-3 document) such as listening and speaking, reading and viewing, writing, thinking and language. The open-ended questionnaire provided a range of steps that the different teachers take:

\section{- Addressing listening as a barrier to learning}

The steps that teachers claim to take to address this barrier include: repeating instructions by speaking slowly and clearly, one-on-one demonstration and slow explanation, a large amount of practical work, establishing and maintaining eye contact with the learners, making use of pictures with words, as well as demonstrating instructions. One teacher at school C mentioned the use of total physical response where learners would listen to language through movements, observation and manipulation of objects and pictures. She also involves learners in problem-solving situations, riddles and brain teasers, and makes use of repetition and revision through the actions of songs, poems and rhymes. 
From the interview with the HODs, formal teaching of listening skills was mentioned as a measure to address listening as a barrier to learning. However, based on the observation by the researchers, the educators did not always seem to apply the various steps that they claimed in their questionnaire responses. They were more concerned with just teaching and getting through the activity, with very little reflection and corrective feedback and not paying attention to whether the learners were listening or not.

Van Staden and Howie (2013:54) report that in many South African classes, textbooks are the only available teaching source used to assist in the teaching of reading. It is the quality of these books which is of grave concern, particularly in rural areas, as they are outdated. However, we do feel that it still provides reading material and is better than having not books at all. Although the DBE does provide book resources to schools in need, very often they do not manage these resources adequately. In many cases the learners are not allowed to take the books home as they may be lost or damaged.

\section{- Addressing speaking as a barrier}

In describing how educators address speaking as a barrier to learning, teachers in general in the 10 participating schools try to teach learners a wider vocabulary by asking them to repeat what they say, for example, using full sentences by talking slowly and clearly about posters and pictures in the classroom. Although teachers admit that they need to be patient with the learners and wait for the learners to explain things, this is not always the case as evidenced in our observations. Breaking words into sections and asking them questions makes it easier for learners to learn. Learners are also given tasks to do in class and they are taught to listen to instructions without interruption. Learners are asked what their interests are, and they are encouraged to participate in role play and to have real conversations by means of simulating exchanges, for example, in the pharmacy and supermarket. Lots of praise and talking to learners during break was found to be very effective for learners to gain confidence to speak spontaneously.

The use of THRASS, Jolly phonics, audio, electronic books, stories, video tapes and computers as well as lots of vocabulary words with pictures are used in the well-resourced schools. The use of correct English while communicating with learners was also stressed. Excessively shy learners are allowed to speak to their teacher alone before participating in a group. Speech therapy is also recommended where the need arises, however, this service is only available at schools which can afford it. Having a conference with parents and discussing the written report with them and informing them in a positive way, for example, to take the learner to the hospital is necessary, as is having at least one person speak English to the learner at home. Generally, the HoDs' interviews revealed that an effort is being made at promoting language development, for example by sending teachers on courses on how to teach language development and other related topics. Although the questionnaire provided impressive responses, the observations of the researchers did not always find evidence to back up the responses.

\section{- Addressing reading and viewing as a barrier}

Educators reported that they employ gross motor and fine motor exercises, correction of eye movement, directionality and laterality exercises, phonics games, repetition, use of finger when reading, using flashcards (large fonts) and reading loudly and slowly (a few times), and teach rhythm and timing every day to address the challenge. The use of pictures to predict 
stories and drama activities is also used to encourage reading. Other interventions included teaching learners high frequency words and reading a story and leaving out the ending (for learners to tell how they think it would end). Big Books are used and learners are asked to identify the beginning and the end of the story and to listen for rhyming words. Learners are also expected to explain what is happening in a picture and they are encouraged to read sight words and to identify the sound at the beginning of words. Continuous assessment is necessary to monitor learners' progress. The interview with the HODs did not offer any remedy for what the interventions must be. From our observations the aforementiond interventions were not evident in all the classes.

A study conducted by Van Staden and Howie (2010:54) reported that teachers had little or no training in the areas of remedial reading and special education. This is cause for concern as the learners' low achievement in reading literacy and large learner variations in the classroom presents a huge challenge. In many schools in South Africa Foundation Phase learners (Grade $1-3$ ) are exposed to only certain reading skills, for example, decoding and vocabulary.

\section{- Addressing writing as a barrier}

Regarding writing as a barrier to learning, educators submitted that it is important to concentrate on good body posture, middle line crossing, pencil grip and body posture. Teachers make learners learn words, fill in words and sequence pictures. It was observed that the learners were often given oral work, with step-by-step instructions. They had to complete one task at a time and were then given the next instruction to be completed before writing sentences, as well as being taught sight words every day. A variety of materials are given to the learners to use to allow them to be creative and they are praised for any effort shown.

Teachers refrain from giving learners activities that are too complex or difficult. Words and examples of sentences are given to learners to learn and oral work is done before writing sentences (by hearing good English spoken as well as pronunciation by the teacher, however, this appears to be a challenge for teachers teaching in their second language). The researchers in some cases observed discrepancies between what the teachers claimed to do about writing in their responses to the questionnaire, and what actually happened in the classrooms. For example, some of the learners did not know how to handle a pencil, thus leading to writing difficulties.

It is disconcerting that teachers are still inclined to interpret the curriculum subjectively, which seems to characterise the way they practice teaching normally as well as the way their colleagues practice teaching. What young learners' writing means to teachers is based more on their usual practice rather than on written objectives or suggested innovations (Gains \& Graham, 2011:85/6) as it features in the CAPS document. These authors found that teachers' approaches to get learners to develop writing skills failed as they do not consider the learners' capacity to be creative and expressive (Gains \& Graham, 2011: 92). There is thus a need to emphasise writing pedagogy for in-service and pre-service teacher education. The majority of early literacy teachers have not had any experience in expressive writing which means it seldom or never happens in early literacy classrooms in public schools (Gains \& Graham, 2011:77). 


\section{- Addressing thinking and reasoning as a barrier}

Teachers responded to the open-ended questions in the questionnaire, that inter alia they use pictures, good language and demonstration when explaining new concepts on the learners' level of understanding. Other activities included storytelling, retelling stories, following instructions, listening, blocks building, cutting big pictures into pieces and then putting them back, speaking and additional assistance (one-on-one or in small groups) as a means of overcoming barriers to thinking. An atmosphere of problem-solving should be created by asking simple problems and offering practical solutions. They can recall facts in the correct sequence. A limitation in this research is that due to time constraints, we were not able to verify whether these interventions truly take place over a period of time.

\section{- Addressing language as a barrier}

Educators indicated the use of letter boards, sight words, picture sentences, labels on items, theme tables, phonic programmes, spelling tests and playing language games to address language difficulties such as phonemic awareness, knowledge of the alphabet, vocabulary and syntax. Other suggestions were that learners make letters out of rough paper and trace over them with their fingers. Learners also clap out words, use pictures to match phonics, listen to story CDs and practice phonics every day. As one teacher in School B put it 'Language is not only a medium of education, but also an outcome of education ....' and what makes it difficult is that '...one has to know something before one can learn it'.

The biggest difference between children from non-English speaking homes and those from English speaking homes is vocabulary. This is particularly relevant to learners who grow up in poverty and who attend under-resourced schools such as those in schools E - J, often resulting in reading difficulties. While the importance of vocabulary is emphasised by Van Staden (2011:18), teaching lists of vocabulary may not be the solution to the problem. Often it is the conceptual structures of words acquired at home or school which are retrieved to be used in reading comprehension, thinking (in the social and physical world) and during discussions (Snow, 2014:16-17, 19). As a whole we found during our observations, that learners had a reasonable command of vocabulary in their mother tongue particularly where the LoLT of the school was their mother tongue. In addition, where learners were given opportunities to talk and where teachers engaged in storytelling and reading and there was a great deal of interactive teacher and learner talk the learners' vocabulary was good. This was especially true of schools A, B, C and D.

\section{CONCLUSION}

The findings reported in this article provide an overview of the status of literacy teaching in selected Grade R classrooms and how teachers address barriers to learning literacy. From the data collected thus far in South Africa, as part of Phase one of the collaborative project, it is clear that teachers' knowledge and skills with regard to teaching literacy to Grade R learners are rather limited, let alone addressing the barriers to literacy learning which they face. This is reason for concern, as international studies have found that many learners in African primary schools do not have the basic literacy levels to progress to higher grades (Akyeampong, Lussier, Pryor \& Westbrook, 2013:272) - something that seems to be a national concern, if one takes the Annual National Assessment results (Department of Basic Education, 2014) of 2014 into account. 
Hoadley (2012:198) expresses concern that a deeper and more robust understanding of instructional practices is needed in order to understand the reasons why South African primary schools are failing the majority of the learners. It should be considered, however, that learners who are 'socialised into multilingual repertoires' and who are exposed to English via visual media and society in the city are differently socialised to those learners who hardly ever hear English in their villages. This means that a viable language policy will need to consider multilingual practices in different contexts and the solution is not a one-size-fits all (Heugh, 2013:229, 231).

The teaching of reading should therefore be adapted to the local conditions and, although literacy is a social practice, it also includes developing 'decoding, comprehension and meaning-making skills', which means that the approach to developing these skills should be redesigned (Janks \& Makalele, 2013:225) It is encouraging that in the CAPS document, factors such as play-based learning, teacher-guided literacy learning and literacy development, which are integrated in other focus areas, are of importance. Phonemic awareness, letter/word recognition, visual memory, vocabulary development, problemsolving, listening and speaking are some of the areas of literacy development which are included in the CAPS for Grade R to Grade 3 (Department of Education, 2011).

Literacy knowledge and skills lay the foundation for reading and writing (early literacy) in all academic tasks. Although this is promising, teachers still need to master the appropriate methodology to teach these skills. In this study it appears that, in most cases, the teaching approach is teacher-centred and children learn by rote. Akyeampong et al. (2013:273) explain that initial teacher education in Africa needs to be addressed and improved, as teachers lack innovative methods and they rely on 'traditional teacher driven lecture, memorisation and recitation teaching styles', a teaching approach which persists in African education.

Nie, Tan, Liau, Lau and Chua (2013:74) found that teachers with a high sense of self-efficacy tend to adopt a constructivist instruction which goes beyond rote memorisation and facilitates the learners' thinking, understanding and communication and which is what constructivist instruction advocates. The implication is that teachers cannot hold on to traditional practices and beliefs as they would be failing to prepare learners for the future. This is also the case in the Grade $\mathrm{R}$ classes in this study and was obvious during our observations as well as the interviews with the HODs.

Akyeampong et al. (2013) argue that initial teacher education should provide teachers with learning experiences where they can 'construct and practice teaching as problem-solving with children at the centre' with particular reference to teaching reading and mathematics during the early grades. Although interventions such as continuing teacher development to improve teacher practice are not discounted by these authors, their research found that initial teacher education does not necessarily empower teachers to understand teaching as problem-solving centered and having an in-depth understanding of learners' learning difficulties and how to address them. These authors recommend that 'we need to develop local pedagogies for teaching our children to read' (Janks \& Makalele, 2013:225-226).

Other challenges which teachers and learners face exacerbate the dire literacy situation in South Africa, as is evidenced in this study. Zuze and Reddy (2014:105) explain that the environment, school and biological factors influence reading literacy development. Socioeconomic conditions, limited resources (including teaching and learning materials), unqualified teachers, lack of basic facilities such as permanent classrooms and a proper water supply, and the LoLT being other than learners' mother tongue are some of the challenges faced by teachers and learners. Age-appropriate education equipment which is durable and 
safe is thus necessary to stimulate learners' early learning of literacy, numeracy and life skills, with proper teacher guidance (Atmore, 2013:159 \& 160). In this project the equipment available in the rural, township and inner city schools in low socio-economic areas was of a markedly lower standard compared to, for example, the private school.

The majority of the teachers who completed the questionnaire admitted that they were illequipped to identify and address barriers to learning, which was also obvious in our observations. The emphasis should be on initial teacher education in Africa which focuses on the problems and challenges that young learners from diverse and multilingual background experience when learning to read, resulting in transforming their learning experiences and contributing to reducing poverty in Africa (Ibid:280). It is important that teacher training opportunities be available in order to produce quality ECD teachers. Currently almost all training opportunities are offered at Further Education and Training colleges and non-profit organisations. It is imperative though that ECD teacher training should focus on ECD teachers acquiring basic skills which can be implemented over a short time for the benefit of the children (Atmore, 2013:157, 160).

\section{ACKNOWLEDGEMENTS}

The authors would like to thank Dr OA Asikhia (post-doctoral fellows) and Dr S Mokiwa for assisting with data collection.

\section{REFERENCES}

AKYEAMPONG, K, K LUSSIER, J PRYOR \& J WESTBROOK. 2013. Improving teaching and learning of basic maths and reading in Africa: Does teacher preparation count? International Journal of Educational Development 33:272-282.

ATMORE, E. 2013. Early childhood development in South Africa - progress since the end of apartheid. International Journal of Early Years Education 21(2-3):152-162.

BIERSTEKER, L \& A DAWES. 2008. Early Childhood Development. Human Resources Development Review. HSRC. Pretoria.

CONDY J, A CHIGONA, R CHETTY \& C THORNHILL. 2010. Final-year teacher training students' perceptions of THRASS. South African Journal of Education 30:261-275.

CRESWELL, JW. 2007. Qualitative Inquiry \& Research Design: Choosing Among Five Approaches. London: Sage.

DEPARTMENT OF BASIC EDUCATION. 2010. The Status of the Language of Learning and Teaching (LoLT) in South African Public schools: a qualitative overview. Pretoria: Department of Basic Education.

DEPARTMENT OF EDUCATION (DoE). 2011a. Curriculum and Assessment Policy Statement (CAPS) - Foundation Phase Home Language Grades R-3. Pretoria: Government Press.

DEPARTMENT OF EDUCATION. 2011b. Curriculum and Assessment Policy Statement (CAPS) - Foundation Phase Grades R-3: English Frist Additional Language Grade $1-3$. Pretoria: Government Press.

DEPARTMENT OF BASIC EDUCATION (DoBE). 2014. Report on the Annual National Assessments, 2014. Grades 1 to 6 \& 9. Pretoria: Department of Basic Education.

DEPARTMENT OF EDUCATION. 2008. National Reading Strategy. Pretoria: Government Printers. 
DEPARTMENT OF EDUCATION (DoE). 2001. Education White Pater 6 Special Needs Education. Building an inclusive education and training system. Pretoria: Department of Education.

FLEISCH, B. 2008. Primary Education in Crisis: Why South African School Children Underachieve in Reading and Mathematics. Cape Town: Juta.

GAINS, P \& B GRAHAM. 2011. Making space for expressive and creative writing in African primary schools: a two-site action research study in Kenya and South Africa. Reading and Writing 2(1):77-94.

HEUGH, K. 2013. Multilingual Education Policy in South Africa constrained by theoretical and historical disconnections. Annual Review of Applied Linguistics, 33:215-237.

HOADLEY, U. 2012. What do we know about teaching and learning in South African primary schools? Education as Change 16(2):187-202.

JANKS, H \& L MAKALELA. 2013. Engaging in visionary: Horizons of the (im)possible. Education as Change 17(2):219-228.

NEL, NM. 2011. Second language difficulties in a South African context. In: Addressing Barriers to Learning: A South African Perspective. Editors E. Landsberg, D Kruger and E Swart. Pretoria: Van Schaik.

NIE, Y, GH TAN, AK LIAU, S LAU \& BL CHUA. 2013. The roles of teacher efficacy in instructional innovation: its predictive relations to constructivist and didactic instruction. Educational Research For Policy And Practice 12(1):67-77.

MATTHEWS, B \& L ROSS. 2010. Research Methods. A practical guide for the social sciences. London: Pearson.

McCARDLE, P \& V CHHABRA. 2004. The Voice of Evidence in Reading. Baltimore: Paul H Brookes Publishing Co.

MCMILLAN, JH \& S SCHUMACHER. 2010. Research in Education. Evidence-based inquiry. Seventh Edition. New York: Pearson.

MURRIS, K. 2014. Philosophy with children as part of the solution to the early literacy education crisis in South Africa. European Early Childhood Education Research Journal 1-16.

O'CARROLL, S. 2011. An exploratory study of early letter-sound knowledge in a low socioeconomic context in South Africa. Reading and writing. 2(1): 7-26.

PATTON, MQ. 2002. Qualitative Research \& Evaluation Methods. Third edition. London: Sage.

PIENAAR, AE, R BARHORST \& JWR TWISK. 2013. Relationship between academic performance, SES school type and perceptual-motor skills in first grade South African learners: NW-CHILD study. CHILD: care, health and development, 40(3):370-378.

SNOW, CE. 2014. Language, literacy, and the needs of the multilingual child. Perspectives in Education, 32(1):11-20.

US DEPARTMENT OF EDUCATION. 2010. The Head Start Child development and Early Learning Framework. Promoting Positive Outcomes in Early Childhood Programs Serving Children 3-5 Years Old. Head Start: Washington.

VAN STADEN, A. 2011. Put reading first: positive effects of direct instruction and scaffolding for ESL learners struggling with reading. Perspectives in Education 29 (4):10-21.

VAN STADEN, S \& S HOWIE. 2010. South African teacher profiles and emerging teacher factors: The picture painted by PIRLS 2006. Reading and Writing 1(1):47-60.

ZUZE, L \& V REDDY. 2014. School resources and the gender reading literacy gap in South African schools. International Journal of Educational Development 36:100-107. 


\section{BIOGRAPHICAL NOTES}

Norma Margaret Nel, a Professor Emeritus, Research Fellow and NRF rated researcher at the University of South Africa. She holds a DED. She supervises Masters and Doctoral students as well as a Post-doctoral fellow. She is actively involved in research related to education on a national and international level. Email: tnelnm@unisa.ac.za

Kesh Mohangi is an associate professor in the Department of Psychology of Education at Unisa. Her research interests include, amongst others, learning and learning support, developmental psychology as well as well-being in schools. Kesh is also an Educational Psychologist registered with the HPCSA. Email: mohank@unisa.ac.za

Soezin Krog is a Senior Lecturer in the Department of Early Childhood Education at Unisa. She holds a D Ed degree and supervises Masters and Doctoral students. Her research interests include, amongst others, early childhood education, physical education, sports coaching and sports psychology. Soezin is also an Educational Psychologist registered with the HPCSA. Email: krogs@unisa.ac.za

Oluyemi Stephens is a Post-Doctoral Fellow at the Department of Psychology of Education, College of Education, University of South Africa. He holds a PhD degree in Counselling Psychology. He has a number of publications in journals as well as book chapters.

Email: stephoa@unisa.ac.za 